\title{
KONSTRUKSI PENDIDIKAN MORAL DALAM FILM BILAL BIN RABAH $A$ NEW BREED OF HERO KARYA AYMAN JAMAL
}

\author{
Akmal Mundiri ${ }^{1}$, Musdalifatul Makkiyah ${ }^{2}$ \\ Muzdalifatulmakkiyah1709@gmail.com² \\ Universitas Nurul Jadid Paiton Probolinggo
}

\begin{abstract}
Moral education is education that encourages people to take good actions. The destruction of the state can occur because of the moral destruction of some of its citizens. Therefore, the construction of moral education has been explained in the hadith of the Prophet Muhammad which addresses the improvement of human morals. There is a lot of moral education in films that do not only act as entertainment, but have the potential as an educational medium that can influence a person's behavior. This study aims to determine how moral education contained in the film Bilal A New Breed Of Hero. The approach used in this study is a qualitative approach with Roland Barthes's semiotic analysis technique. The results of this study indicate that the moral values contained in the film Bilal A New Breed Of Hero are religious values, tolerance, discipline, curiosity, and social care aimed at the younger generation to always be passionate about a chieving more life goals both for the sake of nation and state. Thus, moral education in the film Bilal A New Breed Of Hero contains moral values in various aspects of life through both visual and verbal signs in each story.
\end{abstract}

Keywords: Construction, Moral Education, Film.

\begin{abstract}
Abstrak
Pendidikan moral merupakan pendidikan yang mendorong manusia untuk melakukan tindakan yang baik. Kehancuran negara dapat terjadi karena hancurnya moral beberapa warganya. Oleh karena itu, konstruksi pendidikan moral telah dijelaskan pada hadist Nabi Muhammad yang membahas tentang penyempurnaan akhlak manusia. Pendidikan moral banyak terdapat dalam film yang tidak hanya berperan sebagai hiburan, namun berpotensi sebagai media edukasi yang mampu mempengaruhi perilaku seseorang. Penelitian ini bertujuan untuk mengetahui bagaimana pendidikan moral yang terdapat dalam film Bilal A New Breed Of Hero. Pendekatan yang digunakan dalam penelitian ini adalah pendekatan kualitatif dengan teknik analisis semiotika Roland Barthes. Hasil dari penelitian ini menunjukkan bahwa nilai-nilai moral yang terdapat pada film Bilal A New Breed Of Hero yaitu nilai religius, toleransi, disiplin, rasa ingin tahu, dan peduli sosial yang ditujukan bagi generasi muda agar selalu semangat menggapai cita-cita kehidupan yang lebih baik demi bangsa dan negara. Dengan demikian, pendidikan moral dalam film Bilal A New Breed Of Hero mengandung nilai-nilai moral dalam berbagai sisi kehidupan melalui tanda-tanda baik visual maupun verbal dalam masing-masing ceritanya.
\end{abstract}

Kata Kunci: Konstruksi, Pendidikan Moral, Film. 


\section{PENDAHULUAN}

Baik dan buruknya suatu bangsa dapat dilihat dari kondisi pemudanya. Jika pemudanya baik, maka baiklah kondisi bangsa tersebut. Sebaliknya, jika pemudanya rusak, maka rusaklah bangsa tersebut. Karena ditangan pemudalah kunci perbaikan suatu bangsa. Merekalah yang akan meneruskan perjuangan generasi terdahulu. Di atas pundak mereka ada tanggung jawab yang berat. Untuk mempersiapkan generasi yang benarbenar mampu mengemban amanah bangsa, maka pendidikanlah merupakan satu-satunya cara yang tepat untuk menggembleng para generasi penerus supaya siap menjadi pemimpin di masa yang akan datang dan mampu menghadapi tantangan globalisasi dan modernisasi. Baik itu melalui lembaga pendidikan formal dan non formal.

Pendidikan di seluruh dunia kini sedang mengkaji kembali perlunya pendidikan moral atau pendidikan budi pekerti atau pendidikan karakter dibangkitkan kembali. Hal ini bukan hanya dirasakan oleh bangsa dan masyarakat Indonesia, tetapi juga oleh negara-negara maju. Bahkan di negara-negara industri di mana ikatan moral menjadi semakin longgar, masyarakatnya mulai merasakan perlunya revival (kebangkitan kembali) dari pendidikan moral yang pada akhir-akhir ini mulai diterlantarkan.(Zuriah, 2007). Pendidikan moral merupakan pendidikan yang mengajak manusia untuk melakukan tindakan yang baik. Pendidikan berbasis moral akan sangat berguna bagi peserta didik dalam mengembangkan diri dan bergaul dengan masyarakat. Moral adalah bekal di dalam mengembangkan diri. Hal itu dikarenakan, jika moral telah diam dalam diri, maka manusia akan dapat mempertanggungjawabkan segala aktivitasnya terhadap dirinya sendiri, orang lain dan utamanya kepada Tuhan Yang Maha Esa. Seseorang akan memiliki kesadaran sejati dan pertimbangan yang matang terhadap implikasi-implikasi dari setiap perbuatannya.

Jika memperhatikan dunia pendidikan saat ini, pendidikan moral jarang diajarkan lagi kepada peserta didik. Pendidikan moral sudah dikalahkan oleh pendidikan yang lain seperti matematika, IPA, IPS dan lainnya. Waktu belajar di sekolah digunakan untuk mengejar nilai akademik. Peserta didik dipaksa belajar bersungguh-sungguh agar mendapatkan nilai baik dan bisa mengharumkan nama sekolahnya. Sedangkan pendidik, pelajar, dan pemerintah seakan-akan lupa bahwa ada pelajaran yang lebih penting dari itu semua yaitu pendidikan moral. Pendidikan yang akan dibawa sampai akhir hayat, pendidikan yang akan menentukan bagaimana dia dipandang masyarakat lain kelak, 
pendidikan yang bisa membuat dia menjadi manusia yang berguna, dan pendidikan yang akan membawa dia kelak di surga ataukah di neraka. Hal itu dikarenakan, kerusakan moral seseorang mengganggu ketentraman yang lain. Jika dalam masyarakat banyak orang yang rusak moralnya, maka akan guncanglah keadaan masyarakat itu.(Sahide, Kebebasan dan Moralitas, 2010) Oleh karena itu, pendidikan moral sejak dini sangat dibutuhkan sekali karena sesuai dengan pendapat Emile Durkheim bahwa apabila tahap anak-anak pada masa sekolahnya itu berlalu, belum diletakkan dasar-dasar moralitas, maka dasar-dasar moralitas itu tidak akan pernah tertanam dalam diri si anak.(Durkheim, 1990) Oleh karena itu, pendidikan moral sangat penting bagi kehidupan manusia agar dapat mengubah perilakunya menjadi lebih baik dan mampu menghadapi tantangan jaman yang cepat berubah. (Bertens, 2007)

Pendidikan semacam ini dapat dilakukan dengan berbagai cara yang positif dan menarik, seperti halnya menonton sebuah film. Sebuah film yang baik memiliki makna dan pesan moral yang disampaikan dengan cara yang baik, sederhana dan sekreatif mungkin. Salah satunya dengan film pendidikan yang merupakan suatu tayangan yang bertujuan untuk merubah perilaku seseorang baik itu kognitif, afektif, maupun psikomotor dan tidak bersifat profit oriented. Dengan cara tersebut, penonton diharapkan mampu memaknai film yang ditontonnya dan mengambil pesan moral untuk dapat dijadikan contoh dan motivasi bagi kehidupan mereka. Salah satunya adalah film Bilal bin Rabah A New Breed of Hero karya Ayman Jamal.

Film Bilal bin Rabah A New Breed of Hero karya Ayman Jamal merupakan sebuah film animasi garapan Barajoun Entertainment yang telah masuk jajaran animasi hollywood yang telah mengikuti berbagai ajang festival film dan berhasil menarik perhatian penonton saat diputar di festival film Cannes dengan mendapat penghargaan sebagai "The Best Inspiring Movie" dan penghargaan film inovatif terbaik di BroadCast Pro Middle Eas Award. Film ini banyak mengungkap nilai-nilai moral dan sosial yang ditujukan bagi generasi muda agar semangat menggapai kehidupan yang lebih baik lagi. Film ini diangkat berdasarkan kisah nyata dari salah satu sahabat Nabi Muhammad SAW yakni Bilal Bin Rabah. Ketika Bilal berumur tujuh tahun, ia bercita-cita ingin menjadi seorang ksatria (pemuda yang hebat dengan suara yang indah). Namun, Bilal dan saudari perempuannya diculik oleh Umayyah bin Khalaf dari kampung halamannya dan dijual 
sebagai seorang budak. Bilal dan saudari perempuannya tinggal dalam kehidupan yang penuh dengan kekejaman dan ketidakadilan.

Penelitian serupa baik yang membahas tentang pendidikan moral memang sudah banyak dilakukan oleh beberapa peneliti, misalnya Bagus Fahmi Weisarkurnai di Universitas Riau yang berjudul "Representasi Pesan Moral dalam Film Rudy Habibie Karya Hanung Bramantyo (Analisis Semiotika Roland Barthes)" dan Jaquiline Melissa Mahasiswi Universitas Hasanuddin Makassar yang berjudul "Pesan Moral dalam Film To Kill A Mockingbird". Penelitian-penelitian tersebut lebih banyak membahas dan mengungkap pendidikan moral. Dengan demikian, penelitian yang membahas tentang pendidikan moral lebih banyak dilakukan di tatanan field research, dan jarang sekali dilakukan dalam lingkup sinema atau bahkan novel. Penelitian tentang pendidikan moral dalam film hanya peneliti temukan dalam film Upin Ipin yang telah diteliti pada tahun 2010. Penelitian tersebut mengurai tentang karakter anak yakni nilai-nilai moral yang dapat ditiru oleh anak seperti patuh terhadap orang tua, displin waktu, taat menjalankan ajaran agama, dan sebagainya. Dengan demikian, secara tidak langsung anak dapat meniru tingkah laku yang ada dalam film tersebut. (Basirudin, 2010)

Penelitian tentang konstruksi pendidikan moral tentunya sudah banyak yang melakukan. Namun, perbedaan mendasar antara penelitian yang sudah ada terletak pada obyek penelitiannya. Di antara obyek penelitian yang telah diteliti terkait dengan pendidikan moral adalah Film Upin Ipin dengan fokus meneliti nilai moral sopan santun, displin dan taat. Sedangkan penelitian ini memilih film Bilal Bin Rabah A New Breed Of Hero karya Ayman Jamal sebagai obyek penelitian karena banyak menginspirasi serta mengungkap nilai-nilai moral seperti nilai religius, disiplin, toleransi, rasa ingin tahu, dan peduli sosial yang ditujukan bagi generasi muda agar selalu semangat menggapai citacita kehidupan yang lebih baik demi bangsa dan negara. Berdasarkan uraian di atas, penulis tertarik dengan melakukan penelitian dengan judul "Konstruksi Pendidikan Moral dalam Film Bilal Bin Rabah A New Breed Of Hero karya Ayman Jamal”

\section{METODE PENELITIAN}

Metode yang digunakan mengungkap kontruksi nilai moral dalam film Bilal Bin Rabah A New Breed Of Hero karya Ayman Jamal adalah pendekatan kualitatif dengan teknik analisis semiotika perspektif Roland Barthes, yang memusatkan perhatian pada tanda (sign). Peneliti mencoba menganalisis dan menjawab pertanyaan bagaimana nilai- 
E-ISSN: 2528-2476

nilai moral yang dipresentasikan dalam film Bilal Bin Rabah A New Breed Of Hero karya Ayman Jamal dan bagaimana posisi subjek dan objek mempresentasikan nilai-nilai moral dalam film Bilal Bin Rabah A New Breed Of Hero karya Ayman Jamal. Analisis data yang digunakan dalam penelitian ini bersifat induktif/kualitatif sehingga hasil penelitian kualitatif lebih menekankan makna daripada generalisasi.

\section{HASIL PENELITIAN DAN PEMBAHASAN}

Islam muncul ke dunia bukan merusak kehidupan yang telah ada, akan tetapi Islam datang untuk memperbaiki tatanan kehidupan umat manusia. Ciri utama Islam bukan menimbulkan konflik dan bukan pula memisahkan antara kehidupan spiritual dan keduniaan. Oleh karenanya, pendidikan Islam tidak terbatas pada kata-kata dalam penyucian kehidupan spiritual dan moral seseorang yang terdapat dalam perasaan yang paling dalam, akan tetapi mencakup seluruh unsur kehidupan serta pola-pola aturan sosial yang benar.(Arifin, 2011). Mengingat pentingnya perkembangan moral, tentunya ada sebuah proses yang tidak lepas dari perkembangan moral itu sendiri. Proses yang dimaksud adalah dengan pendidikan. Pendidikan menekankan gerakan mental yang tercermin dalam budi pekerti yang hasilnya terlihat dalam tindakan nyata seseorang, yaitu tingkah laku yang baik.(Wahid, 2018) Pendidikan adalah kodrat bagi manusia. Oleh karena itu, proses pendidikan difokuskan pada pembinaan tiga potensi kejiwaan yaitu rasa, cipta dan karsa yang pembinaannya diarahkan pada kecerdasan spiritual, intelektual dan moral.(Musthan, 2015)

Dalam arti lain, pendidikan diartikan sebagai usaha sadar yang dilakukan oleh seseorang atau kelompok orang lain agar menjadi dewasa dan mencapai tingkatan hidup yang lebih tinggi dalam arti mental.(N, 1992) Pengertian ini mengindikasikan betapa sangat besar peranan pendidikan dalam mewujudkan kepribadian manusia yang utuh dan mandiri serta menjadi manusia yang mulia dan bermanfaat bagi lingkungannya. Dengan pendidikan, manusia akan paham bahwa dirinya itu sebagai makhluk yang dikaruniai kelebihan dibandingkan dengan makhluk lainnya. Seperti dalam Al-Qur'an surat AlMujadalah ayat 11 yang berbunyi:

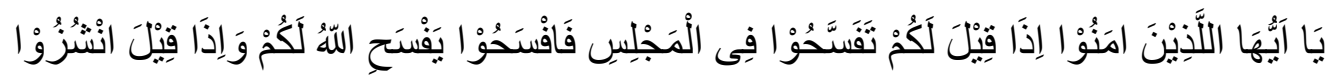

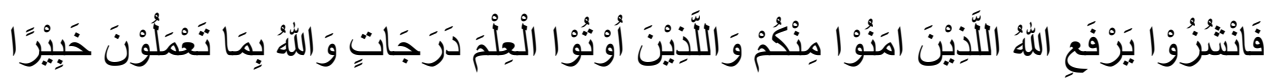

Artinya: "Hai orang-orang yang beriman apabila dikatakan kepadamu: Berlapang-lapanglah dalam majlis", maka lapangkanlah niscaya Allah akan 
memberi kelapangan untukmu. Dan apabila dikatakan: "Berdirilah kamu”, maka berdirilah, niscaya Allah akan meninggikan orang-orang yang beriman diantaramu dan orang-orang yang diberi ilmu pengetahuan beberapa derajat. Dan Allah Maha Mengetahui apa yang kamu kerjakan”. (QS. Al-Mujadalah: 11). Ayat di atas menjelaskan tentang akhlak yang berkaitan dengan perbuatan manusia yaitu perbuatan baik dan buruk. Akhlak sangat berperan dalam pembentukan kualitas manusia yang beriman dan bertakwa. Manusia yang dengan kualitas iman dan taqwa diyakini mampu bertindak bijaksana baik dalam kapsitas sebagai pemimpin bagi dirinya, keluarga maupun masyarakat. (Azami, 2014) Dengan demikian, pendidikan moral sangat penting untuk menghasilkan perubahan yang direalisasikan dalam kenyataan hidup sehari-hari yang meliputi tingkah laku yang baik, cara berfikir yang baik dan bersikap baik yang dapat menghasilkan manusia sempurna. John S. Brubacher mengemukakan, pendidikan adalah proses timbal balik dari setiap individu dengan individu lain yang bertujuan untuk menyesuaikan dirinya dengan alam semesta.(Brubacher, 1958) Pendidikan ini merupakan sebuah upaya yang dilakukan seseorang dalam rangka memupuk (mendidik) dirinya maupun orang lain menuju kedewasaan berfikir untuk terbentuknya kepribadian yang lebih sempurna.

Sedangkan moral adalah perbuatan baik dan buruk yang sesuai dengan ide-ide umum, wajar, dan diterima yang meliputi kesatuan sosial atau lingkungan tertentu.(Ya'kub, 1996) Moral juga bisa digunakan untuk menentukan batas-batas dari sifat, perangai, kehendak, pendapat atau perbuatan yang secara layak dapat dikatakan benar, salah, baik atau buruk. Pengertian moral terdapat dalam buku The Advanced Leaner's Dictionary of Current English. Dalam buku ini dikemukakan beberapa pengertian moral yaitu:

1. Prinsip-prinsip yang berkenaan dengan benar dan salah, baik dan buruk,

2. Kemampuan untuk memahami perbedaan antara benar dan salah

3. Ajaran atau gambaran tingkah laku yang baik.(Nata, 2017)

Berdasarkan kutipan tersebut, menyatakan bahwa moral adalah istilah yang digunakan untuk memberikan batasan terhadap aktivitas manusia dengan nilai (ketentuan) baik atau buruk, benar atau salah. Jika dalam kehidupan sehari-hari orang tersebut bermoral, maka bisa dikatakan bahwa orang tersebut sikap (tingkah lakunya) baik.

Masalah moral dalam kehidupan saat ini adalah suatu masalah yang menjadi perhatian orang dimana saja, baik dalam masyarakat yang telah maju maupun dalam 
masyarakat yang masih terbelakang. Hal tersebut disebabkan kerusakan moral seseorang mengganggu ketentraman yang lain. Jika dalam suatu masyarakat banyak yang rusak moralnya, maka akan goncanglah keadaan masyarakat itu. Oleh karena itu, kesadaran moral merupakan faktor penting untuk memungkinkan tindakan manusia selalu bermoral, berperilaku susila, dan perbuatannya selalu sesuai dengan norma yang berlaku. Kesadaran moral ini didasarkan atas nilai-nilai yang benar-benar esensial atau fundamental. Kesadaran moral erat pula hubungannya dengan hati nurani yang dalam bahasa asing disebut conscience, conscientia, gewissen, geweten, dan dalam bahasa Arab disebut dengan qalb/fu'ad. (Zubair, 1980) Orang yang memiliki kesadaran moral akan senantiasa jujur. Sekalipun tidak ada orang lain yang melihatnya, tindakan orang yang bermoral tidak akan menyimpang dan selalu berpegang pada nilai-nilai tersebut. Hal ini terjadi karena tindakan orang yang bermoral itu berdasarkan atas kesadaran, bukan berdasar pada sesuatu kekuatan apa pun dan juga bukan karena paksaan dari luar, tetapi berdasarkan kesadaran moral yang timbul dari dalam diri yang bersangkutan.

Pendidikan moral bukanlah sebuah topik baru dalam pendidikan. Pada kenyataannya, pendidikan moral merupakan bagian yang tidak terpisahkan dalam proses pendidikan. Beberapa hal yang berkaitan dengan pendidikan moral, yakni:

1. Pendidikan karakter merupakan pendidikan yang bersentuhan langsung dengan perkembangan moral anak

2. Klarifikasi nilai adalah proses memberikan bantuan kepada setiap anak untuk memahami dan menyadari untuk apa hidup serta mengklarifikasi bentukbentuk perilaku apa yang layak dikerjakan

3. Pendidikan moral kognitif adalah pendekatan yang didasarkan pada keyakinan bahwa murid harus mempelajari hal-hal seperti demokrasi dan keadilan saat moral mereka sedang berkembang.(Gunadi, 2013)

Pendidikan moral adalah penanaman, pengembangan dan pembentukan akhlak yang mulia dalam diri manusia. Pendidikan moral harus merupakan satu program atau pelajaran khusus, akan tetapi merupakan suatu dimensi dari seluruh usaha pendidikan. Ini berarti bahwa moral seseorang itu dapat dipupuk dan dapat dikembangkan menuju tingkat perkembangan yang sempurna dalam suatu proses pendidikan.(Surur, 2010) Menurut pandangan Muhammad al-Ghazali, moralitas seseorang dapat ditegakkan dengan syahadat Tauhid karena dengan mengucapkan syahadat, maka dia mengikrarkan langkah dalam pentas kehidupan ini sesuai dengan garis yang berlawanan dengan orangorang musyrik dan musuh Allah. Dengan syahadat itu pula, dia telah menegaskan 
pandangan dunia dalam segala perkara yang menyibukkannya siang dan malam.(AlGhazali, 1990)

Moral atau akhlak manusia dalam perspektif islam itu sangat penting disebabkan belajar dari tingkah laku atau akhlak Rasulullah yang begitu mulia yang sepatutnya dicontoh seperti apa perilaku beliau. Rasulullah bersanda dalam hadistnya:

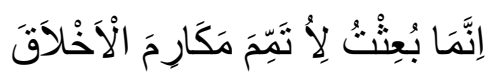

Artinya: "Sesungguhnya aku diutus hanya untuk menyempurnakan akhlak".

Dalam pandangan Islam, dijelaskan dalam hadist Nabi Muhammad SAW tentang memperbaiki akhlak manusia, tentunya pada saat masa jahiliyah tidak ada moral atau akhlak dalam kehidupan masyarakat. Maka saat ini, nikmatnya Islam sangat luar biasa dengan diaturnya kehidupan manusia yang bermoral.

Islam memberikan pendidikan moral yang tinggi dalam kehidupan. Oleh karena itu, pendidikan moral dalam Islam sangat penting, agar tidak menimbulkan suatu hal yang menyimpang dari ajaran Islam, baik secara agama atau norma-norma yang berlaku disekitar. Islam datang untuk mengajarkan tentang bagaimana cara menempuh kehidupan yang penuh dengan kesopanan dan penuh dengan kepribadian yang baik. Belajar dari Rasulullah adalah sebagai awal untuk memperbaiki nilai moral atau akhlak. Apa yang dilarang oleh Allah merupakan bentuk kasih sayang Allah agar tidak terjadinya suatu bahaya dalam kehidupan manusia. Dengan demikian, pendidikan moral yang lebih stategis harus berdasarkan ketentuan Al-Qur'an dan Sunnah sehingga moral menjadi lebih baik.

Film Bilal Bin Rabah A New Breed of Hero karya Ayman Jamal ini diangkat berdasarkan kisah nyata dari salah satu sahabat Nabi Muhammad SAW. yakni Bilal Bin Rabah. Film ini dimulai sejak kehidupan masa kecil Bilal. Di masa kecilnya, Bilal menikmati hidup bahagia bersama ibu dan adik perempuannya digubuk yang sederhana dan jauh dari hiruk piruk kota. Ketika Bilal berumur tujuh tahun, ia bercita-cita ingin menjadi seorang ksatria (pemuda yang hebat dengan suara yang indah). Namun, Bilal dan saudari perempuannya diculik oleh Umayyah bin Khalaf dari kampung halamannya dan dijual sebagai seorang budak. Bilal dan saudari perempuannya tinggal dalam kehidupan yang penuh dengan kekejaman dan ketidakadilan. Bilal dan Ghufairo (saudari perempuannya) selalu disiksa dan diganggu oleh Shafwan (putra Umayyah). 
Kisah Bilal merupakan kisah menarik yang menceritakan tentang sebuah perjuangan mempertahankan aqidah. Kisah yang insyaAllah tidak membuat bosan walaupun diulang-ulang sepanjang zaman. Bilal adalah seorang budak yang menjadi "Muadzin Islam" pertama dan termasuk salah satu sahabat Nabi Muhammad SAW. Bilal adalah seorang laki-laki yang berhasil mengilhami manusia dengan kekuatannya melawan perbudakan, penindasan, diskriminasi, penyampaian akan keadilan, kesetaraan dan gagasan tentang suatu ajaran dibawah naungan Tuhan.

Setiap orang Islam adalah umat yang harus mengikuti atau mencontoh kepada apa yang telah diajarkan oleh Rasulullah. Sebagai seorang hamba yang terpilih oleh Allah SWT, Rasulullah diperintah untuk menyempurnakan akhlak yang mulia bagi umat manusia. Manusia sebagai pelaksana rencana-rencana Allah menurut al-Qur'an disebut sebagai khalifah di muka bumi, maka manusialah yang secara penuh berkewajiban menampakkan sifat-sifat dan asma-asma Allah yaitu mempergunakan benda-benda alam menurut nasehat, teori dan konsep agama.

Agama tidak dapat dipahami hanya dalam kerangka identitas formal (Islam, Kristen, Hindu, Buddha dan sebagainya). Namun, ia harus dipahami dalam kerangka “nilai-nilai" teologis yang terkandung di dalamnya.(Fawaid, 2016) Dalam perspektif Islam, agama merupakan dasar dan pengantar kehidupan yang mana di dalamnya menyatu nilai-nilai yang tertanam dalam 'aqidah yang berupa sistem keimanan yang mengikuti suatu pendirian, sikap, perilaku dan kehidupan orang yang memilikinya.(Mundiri, 2015)

Islam merupakan agama yang mengajarkan tentang nilai-nilai kebaikan untuk ditaati dan keburukan untuk ditinggalkan. Namun, dalam praktiknya masih banyak orang yang keliru dengan perspektif ajaran Islam. Oleh sebab itu, perlu adanya pencerahan, baik secara konsep maupun perilaku mengenai tata cara hidup yang Islami. Pencerahan tersebut bisa dilakukan dengan berdakwah, yakni mengajak seseorang dengan mengamalkan ajaran agama Islam dan menyampaikan pesan-pesan kebaikan kepada orang yang kurang mengerti. Dalam konteks modern ini, strategi berdakwah yang dapat dilakukan oleh umat Islam sangatlah bervariatif. Yakni, salah satunya dengan menggunakan film.(Sujana, 1995) Film mampu menjangkau psikologis penonton yang sangat digemari oleh seluruh elemen masyarakat. Kehadiran film mampu sebagai media dakwah apabila dalam film tersebut diselingi dengan nilai-nilai kebenaran, yakni 
mengajak dan menyeru, maka kehadiran film secara tidak langsung mengajak penonton untuk melaksanakan kebaikan-kebaikan seperti yang telah dilakukan oleh pemeran utama.

Nilai moral merupakan hal penting yang bisa dijadikan pedoman bagi seseorang dalam berprilaku baik menurut ajaran agama Islam yang harus disampaikan kepada umat Islam guna melaksanakan amar ma'ruf nahi munkar. Nilai-nilai moral pada umumnya mempengaruhi sikap dan perilaku seseorang. Oleh karena itu, untuk mengetahui nilai moral seseorang harus melalui fakta-fakta moral yang berupa tindakan, tingkah laku, pola pikir dan sikap seseorang atau sekelompok orang, termasuk salah satunya adalah perilaku yang dimainkan oleh tokoh-tokoh dalam film Bilal bin Rabah A New Breed of Hero karya Ayman Jamal. Di bawah ini merupakan 18 nilai-nilai moral yang ada dalam kehidupan, diantaranya yaitu nilai religius, jujur, toleransi, disiplin, kerja keras, kreatif, mandiri, demokratis, rasa ingin tahu, semangat kebangsaan, cinta tanah air, menghargai prestasi, bersahabat, cinta damai, gemar membaca, peduli lingkungan, peduli sosial, dan tanggung jawab.(Zubaedi, 2012). Nilai-nilai moral yang terdapat dalam film Bilal bin Rabah A New Breed of Hero karya Ayman Jamal disesuaikan dengan 18 nilai karakter atau moral yang dikembangkan oleh Diknas. Ada 5 nilai karakter atau moral yang terdapat dalam film Bilal bin Rabah A New Breed of Hero karya Ayman Jamal, diantaranya sebagai berikut:

\section{a. Nilai Religius}

Religius adalah nilai yang bersumber pada kepercayaan dan keyakinan dalam diri manusia. Nilai ini penting sekali untuk diteliti karena nilai religius memiliki nilai yang kaitannya dengan Tuhan dan ajaran agama Islam. Dalam film animasi Bilal bin Rabah A New Breed Of Hero karya Ayman Jamal, terdapat 2 nilai religius diantaranya:

\section{Ketaatan}

Pada rangkaian pembukaan, terdapat nilai religius seperti ketaatan seorang anak laki-laki yang bernama Bilal. Bilal berpakaian rapi dan bertopeng. Bilal berlari mengejar saudari perempuannya dengan membawa boneka milik saudarinya. Kemudian Bilal tersenyum karena menemukan saudari perempuannya yang sedang bersembunyi di balik jemuran. Lalu, saudarinya mendatangi Bilal dengan merebut boneka miliknya yang berada ditangan Bilal. Mereka saling tarik- 
menarik bonekanya. Kemudian, ibunya datang dan berkata: "sudahlah sudah" (menit 03:39). Dari larangan tersebut, Bilal menunduk menunjukkan kehormatannya kepada ibunya. Bilal sadar dengan apa yang ia lakukan itu salah. Sehingga sebagai anak yang lebih tua, Bilal memilih untuk mengalah. Bilal memberikan boneka tersebut kepada saudari perempuannya. Bilal mentaati ibunya yang sedang menasehatinya ketika saling berebutan boneka dengan saudari perempuannya. Sikap Bilal yang taat, membuat ibunya senang dan memeluknya dengan pelukan kasih sayang.

Ketaatan Bilal tampak pula ketika Bilal duduk berdua dengan saudarinya yang berdialog dengannya di kamar, mereka saling berpandangan. Ini menunjukkan mereka saling berpikir dan khawatir. Kemudian ada suara yang mengharuskannya untuk melayani tuannya, yaitu dengan memberikan air untuk tuannya. Bilal langsung bangkit dan mengambil dua timba dengan tangan kanan untuk mengambil air. Ini menunjukkan kebaikan dalam melakukan pekerjaan dengan tangan kanan. Dalam perjalanannya mencari air, Bilal membawa dua timba itu sambil meletakkan di punggungnya dengan tangan kanannya yang bersih dan suci. Bilal terus berjalan dengan membawa dua timba untuk diisi air yang akan ia berikan kepada tuannya.

Suatu hari, Bilal duduk di atas bangunan seraya merenung dengan kedua mata yang mengeluarkan air mata. Menunjukkan bahwa ia sedang mengingat sesuatu yang ada dalam benaknya. Bilal teringat pesan ibunya yang membahas tentang mimpi-mimpinya ketika dewasa kelak. Kemudian Ghufaira datang dari belakang Bilal dan menghampiri Bilal serta duduk berdua dengan memberikan uang milik Bilal yang ditemukan karna hilang. Ghufaira memberikan uang tersebut kepada Bilal dengan menggunakan tangan kanan. Karena dengan menggunakan tangan kanan tersebut Ghufaira telah bersikap sopan kepada Bilal. Namun, Bilal menolaknya dengan kata-kata yang ia yakini bahwa Rahmat datang dari hadiah kecil bukan pengorbanan dari sang Dewa. Bilal tetap meyakini bahwa bukan dewa yang bisa mengubah segalanya. Abu Bakar juga berhati mulia dan taat terhadap perintah Tuhannya. Ia sedang duduk sembunyi-sembunyi ketika Bilal sedang menolong anak kecil yang meminta-minta. Ini menunjukkan bahwa Abu Bakar 
sedang memperhatikan Bilal dari kejauhan. Kemudian, ia menyebarkan kebenaran kepada Bilal.

Bilal taat tanpa menentang tindakan tuannya ketika perutnya ditindih batu. Bilal dengan wajah tenang dan sabar dalam melaksanakan perintah tuannya. Ini menunjukkan bahwa ia menerima semua apa yang dilakukan oleh tuannya terhadap Bilal. Ia juga teguh terhadap aqidahnya. Ia tetap memilih Allah sebagai Tuhannya Yang Maha Esa. Ia mengucapkan kata “Ahad! Ahad! Ahad!” (menit 63:56). Dalam perktaannya, Bilal mengucapkan kalimat tersebut seraya mengangkat jari telunjuknya yang menandakan bahwa Allah itu Esa.

\section{Sopan Santun}

Sikap sopan santun seperti Bilal yang duduk seraya menunduk dengan tanda hormat dan taat. Bilal mendengarkan nasehat imam yang menasehatinya dan memberitahu kepada Bilal tentang kebenaran. Sikap Bilal pula yang patuh dan sopan, ketika ia berlari dengan cepat sambil menundukkan kepalanya untuk memanggil tuan Shafwan karna ayahnya membutuhkannya. Bilal duduk seraya menunduk di depan Shafwan. Ini menunjukkan bahwa Bilal hormat dan sopan kepada tuannya.

Dalam nilai religius tersebut diajarkan mengenai cara membiasakan sikap mematuhi perintah yang diamanahkan kepada seseorang dalam melakukan sesuatu. Seperti halnya pendidikan. Dalam pendidikan, upaya mengarahkan seluruh gerak dan tingkah laku manusia menuju kesempurnaan akhlak yang akan dijalaninya kelak. Tentunya, dalam pendidikan terdapat peraturan yang berlaku untuk peserta didik. Misalnya, sikap peserta didik untuk patuh kepada semua perintah gurunya dan patuh terhadap peraturan-peraturan sekolah. seperti contoh: diperintah untuk mengerjakan tugas, berdo'a sebelum belajar, mengumpulkan tugas tepat waktu dan lain sebagainya. Peserta didik tidak untuk didik, diajari dan mencari ilmu saja, namun harus memiliki adab. Karena dalam adab tersebut sudah mencakup pendidikan dan pengajaran.

Hal ini sesuai dengan pemikiran Syed Muhammad Nuqaib Al-Attas, Bahwasanya pendidikan yang tepat adalah ta'dib (adab) bukan tarbiyah (pendidikan) ataupun ta'lim (pengajaran). Sebab kesalahan dalam pemilihan dan pemakaian istilah yang digunakan untuk konsep kebudayaan, keagamaan dan 
spritual dapat menyebabkan kebingungan dalam ilmu dari sudut teori amalan, akhirnya timbul kerancuan dalam berpikir. Kerancuan berpikir akan mengakibatkan kesalahan dalam memahami ilmu, kesalahan dalam memahami ilmu akan mengakibatkan kesalahan dalam menerapkan ilmu itu sendiri. Ta'dib sendiri sudah memuat kandungan tarbiyah dan ta'lim. Oleh karena ta'dib merupakan solusi yang tepat untuk menjawab tantangan pendidikan Islam masa kini.(Al-Attas, 1984)

\section{b. Toleransi}

Toleransi merupakan sikap dan tindakan yang menghargai perbedaan agama, suku, etnis, pendapat, sikap, dan tindakan orang lain yang berbeda dari dirinya. Sikap toleransi dalam film Bilal bin Rabah A New Breed Of Hero karya Ayman Jamal ada dua, yaitu:

1. Terdapat pada Abu Bakar yang berdialog dengan Umayyah. Mereka saling berdampingan seraya menyaksikan siksaan terhadap Bilal. Abu Bakar menyatakan bahwa persaudaraan itu ada pada setiap muslim. Namun, Umayyah menolak persaudraan tersebut. Hal ini tampak bahwa Abu Bakar memiliki sikap toleransi (menghargai) agama lain dengan menganggapnya saudara, sedangkan Umayyah tidak menginginkan orang yang beda agama merupakan saudara baginya.

2. Terwujud dalam perilaku Bilal yang ketika itu ia mengantarkan makanan untuk tuan dan tamunya. Kemudian, Umayyah mengetahui bahwa Bilal memiliki teman baru yang muslim. Bilal disindir dan disiksa. Ini menunjukkan celaan. Bilal berjalan dengan membawa nampan menuju botol yang jatuh dilempar oleh Umayyah, kemudian Bilal duduk dan mengambil botol tersebut. Bilal menjatuhkan botol yang dibawanya dengan nampan. Lalu ia membalikkan badannya dengan tegas berkata: "Kita dilahirkan semua sama, menghirup udara yang sama, darah kita sama merah, kita akan mati dan dikuburkan, sama kembali ke tanah. Aku percaya, bahwa aku lelaki yang bebas, sama sepertimu.” (menit 52:34). Bilal menyatakan kebenaran di depan Umayyah dan tamu-tamunya.

Berdasarkan sikap toleransi di atas, sangat jelas bahwa sikap toleransi penting bagi manusia dalam kehidupannya. Sikap toleransi tidak hanya ada dalam beragama, melainkan juga terletak pada ranah pendidikan yang mengajarkan peserta didik untuk memiliki sikap toleransi, yakni toleransi terhadap sesama teman, dan toleransi antar 
sekolah. Seperti contoh: Menghargai hasil belajar teman yang kurang memuaskan dengan tidak melecehkannya dan menghargai kegiatan ekstrakurikuler antar sekolah meskipun lebih unggul dari sekolah tersebut. Dengan demikian, peserta didik telah memiliki sikap moral yang baik. Pandangan Islam mengenai toleransi terdapat dalam al-Qur'an surah Al-Mumtahanah: (60) 8. Yang berbunyi:

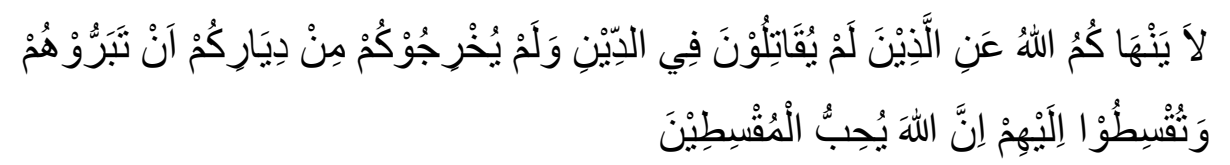

Artinya: "Allah tidak melarang kamu untuk berbuat baik dan berlaku adil terhadap orang-orang yang tiada memerangimu karena agama dan tidak pula mengusir kamu dari negerimu. Sesungguhnya Allah menyukai orang-orang yang berlaku adil." (QS. Al-Mumtahanah (60) 8).

Islam tidak melarang adanya persaudaraan dan toleransi antar umat beragama, selama masih berada dalam tataran kemanusiaan dan kedua belah pihak menghormati hak-hak masing-masing. Umat Islam dianjurkan untuk menjalin persaudaraan, persatuan, dan kesatuan dalam masyarakat, dan saling menghargai serta menghormati antar sesama.

\section{c. Disiplin}

Disiplin merupakan perasaan taat dan patuh terhadap nilai-nilai yang dipercaya termasuk melakukan pekerjaan tertentu yang menjadi suatu tanggung jawab. Disiplin merupakan tindakan yang menunjukkan perilaku tertib dan patuh terhadap berbagai ketentuan dan peraturan. Sikap displin dalam film Bilal bin Rabah A New Breed Of Hero karya Ayman Jamal terdapat pada Bilal dan Ghufaira, mereka selalu tepat waktu dalam melaksanakan perintah. Tepat pada pagi hari ketika matahari sedang terbit dari ufuk timur, Ghufaira melihat Bilal dengan perasaan panik. Ia khawatir pelayanan terhadap tuannya terlambat. Bilal menunduk dengan perasaan khawatir seraya memberitahu Ghufaira tentang keadaan sebelumnya. Kemudian Bilal segera berangkat dengan memakai baju warna krem dengan tangan membawa nampan berisi makanan untuk tuan dan tamunya. Dari sikap Bilal dan Ghufaira di atas, diajarkan sikap disiplin dalam mengerjakan sesuatu, yakni dengan perilaku yang menunjukkan upaya sungguh-sungguh dalam mengatasi berbagai hambatan belajar dan tugas, serta 
menyelesaikan tugas dengan sebaik-baiknya. Seperti kedisiplinan Bilal melaksanakan tugas dari tuannya untuk melayani dengan disiplin, tidak pernah terlambat.

Dalam pendidikan, kedisiplinan sangat penting untuk membiasakan peserta didik dalam melaksanakan tugas dan mematuhi peraturan sekolah dengan sebaikbaiknya. Dengan disiplin, peserta didik tidak akan terlambat sekolah. Ia akan datang tepat waktu. Sebagaimana firman Allah dalam QS. Hud: 112 yang berbunyi:

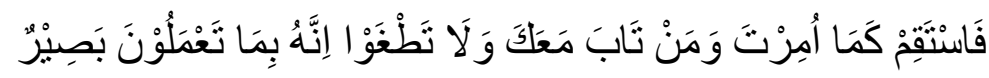

Artinya: Maka tetaplah engkau (Muhammad) di jalan yang benar sebagaimana telah diperintahkan kepadamu dan juga orang yang bertobat bersamamu, dan janganlah kamu melampaui batas. Sungguh Dia Maha melihat apa yang kamu kerjakan. (QS. Hud: 112).

\section{d. Rasa Ingin Tahu}

Rasa ingin tahu adalah sikap dan tindakan yang selalu berupaya untuk mengetahui lebih mendalam dan meluas dari sesuatu yang dipelajarinya, dilihat dan didengar. Sikap rasa ingin tahu dalam film Bilal bin Rabah A New Breed Of Hero karya Ayman Jamal, terdapat pada Bilal yang memiliki rasa ingin tahu tentang perkataan Abu Bakar yang dalam perkataannya "Keinginan memilih takdir" (menit 47:19). Perkataan tersebut membuat Bilal bertanya-tanya, siapa Tuhan yang sebenarnya. Keinginannya untuk mengetahui kebenaran, Bilal datang dengan berpakaian sopan menemui Abu Bakar yang duduk di atas batu seraya memegang tongkat miliknya. Bilal meminta Abu Bakar untuk membimbingnya menuju jalan yang benar. Bilal berdiri dengan bertanya banyak hal kepada Abu Bakar. Kemudian Bilal berdialog dengan Abu Bakar seraya duduk di atas batu di sebuah pantai

Berdasarkan sikap penasaran Bilal tersebut menunjukkan bahwa sikap rasa ingin tau itu perlu, sebab dengan memilki sikap tersebut, seseorang bisa mengetahui apa yang tidak ia ketahui sebelumnya. Ia akan berusaha dengan sungguh-sungguh untuk mendapatkan apa yang ingin ia ketahui. Hal ini berkaitan dengan firman Allah dalam QS. Al-Ankabut: 69, yang berbunyi:

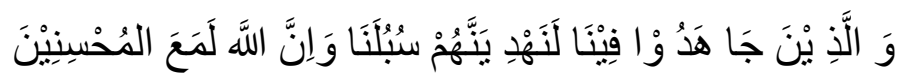

Artinya : "Dan orang-orang yang berjihad untuk (mencari keridhoan) Kami, Kami akan tunjukkan kepada mereka jalan-jalan Kami. Dan sungguh, Allah beserta orang-orang yang berbuat baik." 
Ayat tersebut menjelaskan bahwa sikap ingin tahu akan menuntut seseorang dengan bersungguh-sungguh dalam mencari informasi (pengetahuan) yang belum ia ketahui. Seperti halnya dalam pendidikan yang merupakan usaha sadar seseorang untuk merubah pengalamannya dari tidak tahu menjadi tahu. Tujuan utama dalam pendidikan adalah membina kemampuan berkreatifitas agar segala perubahan yang bermanfaat bagi kelangsungan dan perkembangan kehidupan dapat dicipta.

\section{e. Peduli Sosial}

Peduli sosial merupakan sikap dan tindakan yang selalu ingin memberi bantuan pada orang lain dan masyarakat yang membutuhkan. Sikap peduli sosial dalam film Bilal bin Rabah A New Breed Of Hero karya Ayman Jamal ada 2, yaitu:

1. Terdapat pada Bilal terhadap saudari perempuannya ketika disiksa oleh Shafwan. Bilal datang dengan memikul timba di punggungnya, lalu ia membantu saudarinya dari siksaan Shafwan. Ia melawan Shafwan hingga Shafwan jatuh. Lalu, Bilal memeluk saudarinya dengan pelukan kasih sayang kakak terhadap adik.

2. Bilal datang dengan menggendong tas yang berisi makanan, lalu ia menarik tangan si Bocah kecil yang mengenakan pakaian kotor dengan kondisi kelaparan untuk tidak mencuri uang yang ada di tangan patung. Lalu, Bilal duduk dengan memegang bahu si Bocah kecil. Bilal menasehatinya untuk tidak melakukan hal yang dilarang tersebut. Bilal menolongnya dengan memberi makanan untuknya.

Berdasarkan tindakan di atas, diajarkan tentang tolong menolong terhadap sesama yakni memiliki rasa peduli. Peduli sosial juga bisa diterapkan dalam lingkungan pendidikan. Karena peserta didik tidak hanya dituntut untuk mencari ilmu, namun ia juga dididik dengan pendidikan moral yang bisa melatih mereka dalam berbuat kebaikan. Salah satunya dengan memiliki rasa peduli terhadap teman dan lingkungannya. Salah satu petunjuk yang berkaitan dengan sikap peduli terhadap manusia dan alam sekitarnya, adalah firman Allah SWT :

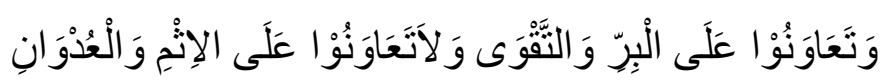

Artinya: "Dan tolong menolonglah kalian dalam kebaikan dan takwa dan janganlah kalian tolong menolong dalam perbuatan dosa dan permusuhan." (QS. Al-Maidah (5): 2).

Ayat tersebut menjelaskan sikap peduli terhadap manusia dan lingkungan sekitar. Oleh karena itu, ayat tersebut menunjukkan agar seluruh umat Islam 
melakukan perbuatan tolong menolong dalam melakukan kebaikan dan mencegah kemungkaran.

Penelitian serupa yang membahas tentang pendidikan moral, penulis temukan pada penelitian yang telah diteliti oleh Basirudin, mahasiswa di Institut Agama Islam Negeri Purwokerto 2010 yang berjudul Nilai-nilai Moral dalam Film Serial Kartun Upin dan Ipin. Penelitian tersebut mengurai tentang karakter anak yakni nilai-nilai moral yang dapat ditiru oleh anak seperti patuh terhadap orang tua, displin waktu, taat menjalankan ajaran agama, dan sebagainya. Dengan demikian, secara tidak langsung anak dapat meniru tingkah laku yang ada dalam film tersebut. (Basirudin, 2010) Persamaannya yaitu sama-sama membahas tentang pendidikan moral. Namun, perbedaannya terletak pada objeknya. Objek yang diteliti adalah Film Upin Ipin dengan fokus meneliti nilai moral sopan santun, displin dan taat. Penelitian yang kedua terdapat pada penelitian yang diteliti oleh Ishmatun Nisa, mahasiswi Universitas Islam Negeri Syarif Hidayatullah dengan judul Analisis Semiotika Pesan Moral Dalam Film Jokowi. Penelitian ini menunjukkan bahwa film Jokowi mengandung pesan moral dalam berbagai sisi kehidupan melalui tanda-tanda yang muncul baik visual maupun verbal di dalam masing-masing ceritanya. Sehingga anak dapat mencontoh karakter yang ada dalam film Jokowi tersebut. Persamaannya yaitu sama-sama meneliti tentang moral. Namun, perbedaannya juga terletak pada objeknya. objek yang diteliti adalah Film Jokowi yang hanya fokus meneliti nilai moral sopan santun. (Nisa, 2012) Sedangkan alasan peneliti memilih film Bilal Bin Rabah A New Breed Of Hero karya Ayman Jamal dalam penelitian ini, karena film ini banyak menginspirasi serta mengungkap nilai-nilai moral seperti nilai religius, disiplin, toleransi, rasa ingin tahu, dan peduli sosial yang ditujukan bagi generasi muda agar selalu semangat menggapai cita-cita kehidupan yang lebih baik demi bangsa dan negara.

Dengan demikian, sangat jelas persamaan dan perbedaan yang ditemukan dari beberapa penelitian di atas dengan penelitian yang peneliti lakukan. Sehingga peneliti dapat membandingkan, menambahi dan membatasi fokus penelitian yang menjadi tujuan penelitian. Agar tidak terjadi pengulangan atau penelitian yang telah ditemukan sebelumnya. Nilai-nilai moral yang terdapat pada film Bilal bin Rabah A New Breed of Hero karya Ayman Jamal tersebut merupakan pelajaran atau pendidikan bagi 
seseorang untuk memperbaiki perilaku dalam bermoral dan sesuai dengan ajaran agama Islam guna melaksanakan amar ma'ruf nahi munkar. Film yang terbaik adalah film yang tidak hanya sukses dalam menghibur tetapi juga film yang dapat mendidik penontonnya. Oleh karena itu, seseorang dikatakan bermoral, jika ia tidak hanya menekankan istilah tarbiyah maupun ta'lim melainkan disertai dengan ta'dib.

\section{SIMPULAN DAN SARAN}

Berdasarkan pembahasan di atas, ditemukan bahwa pendidikan moral dalam film Bilal A New Breed Of Hero mengandung nilai-nilai moral dalam berbagai sisi kehidupan melalui tanda-tanda baik visual maupun verbal dalam masing-masing ceritanya. Nilai moral religius dalam film Bilal yaitu ketaatan dan sopan santun Bilal dalam menghormati ibunya dalam menegurnya ketika Bilal bertengkar dengan saudari perempuannya. Nilai moral toleransi tampak pada Abu Bakar dan Umayyah yang membahas tentang persaudaraan dan menghargai agama lain. Nilai moral disiplin terdapat pada Bilal dan Ghufaira yang selalu tepat waktu dalam melaksanakan perintah. Nilai moral rasa ingin tahu tampak pada Bilal dan Abu Bakar yang memberitahu Bilal tentang sesuatu yang membuat Bilal penasaran akan hal itu. Kemudian nilai moral peduli sosial yang tampak pada Bilal ketika menolong bocah kecil yang sedang kelaparan. Nilai-nilai moral tersebut merupakan pelajaran atau pendidikan bagi seseorang untuk memperbaiki perilaku dalam bermoral melalui ajaran agama Islam untuk melaksanakan amar ma'ruf nahi munkar.

Pendidikan moral merupakan pelajaran atau pendidikan bagi seseorang untuk memperbaiki perilaku dalam bermoral dan sesuai dengan ajaran agama Islam guna melaksanakan amar ma'ruf nahi munkar. Film yang terbaik adalah film yang tidak hanya sukses dalam menghibur tetapi juga film yang dapat mendidik penontonnya. Oleh karena itu, seseorang dikatakan bermoral, jika ia tidak hanya menekankan istilah tarbiyah maupun ta'lim melainkan disertai dengan ta'dib. Pendidikan moral adalah penanaman, pengembangan dan pembentukan akhlak yang mulia dalam diri manusia. Pendidikan moral harus merupakan satu program atau pelajaran khusus, akan tetapi merupakan suatu dimensi dari seluruh usaha pendidikan. Ini berarti bahwa moral seseorang itu dapat dipupuk dan dapat dikembangkan menuju tingkat perkembangan yang sempurna dalam suatu proses pendidikan. Oleh karena itu, pendidikan memiliki makna yang cukup filosofis (mendalam), karena dalam kata mendidik telah termuat sebuah pengarahan moral, etika, sifat, bahkan akhlak yang harus diaplikasikan seseorang ketika menjalani proses pendidikan. 


\section{DAFTAR PUSTAKA}

Al-Attas, S. M. (1984). Konsep Pendidikan dalam Islam, ter. Haidar Bagir. Bandung: Mizan.

Al-Ghazali, M. (1990). Al-Janibu Al-Athifi min Al-Islam. Mesir: Dar Al-Dakwah.

Arifin, Z. (2011). Pendidikan Moral Dalam Multi Perspektif . Sosial Budaya Volume. 8, Nomer. 01 januari-Juni, 11.

Azami, Komarullah. 2014. Nilai-nilai Pendidikan Akhlak Dalam Surat Al-Mujadalah Ayat 11. Jakarta: UIN Syarif Hidayatullah.

Basirudin. (2010). Nilai-nilai Moral Dalam Film Serial Kartun Upin Dan Ipin. Purwokerto: STAIN.

Bertens, K. (2007). Etika. Jakarta: Gramedia Pustaka Utama.

Brubacher, J. S. (1958). Modern Filoshofis of Education in Cultural Perspektive. New York: The Dryden Press.

Durkheim, E. (1990). Pendidikan Moral, Suatu Studi Teori dan Aplikasi Sosiologi Pendidikan, alih bahasa : Lukas Ginting. Jakarta: Erlangga.

Fawaid, A. (2016). Sumbangsih Pendidikan Islam dalam Pembentukan Generasi Eksistensialis. At-Turas Volume. 3. Nomer. 1. Januari-Juni , 9.

Gunadi, R. A. (2013). Membentuk Karakter Melalui Pendidikan Moral Pada Anak Usia Dini di Sekolah Raudhatul Athfal (RA. Habibillah). Ilmiyah WIDYA Volume. 1, Nomer. 2 Juli-Agustus , 2-3.

Mundiri, A. (2015). Kometmen Organisasional Sumber Daya Manusia dalam Meningkatkan Mutu Pendidikan Pesantren. Pendidikan Pedagogik Volume. 03. Nomer. 01. ember, 6-7.

Musthan, Z. (2015). Model Pembelajaran PAI Berbasis TIK Yang Valid dan Efektif Pada SMAN 4 Kendari. Jurnal Of EST Volume. 1, Nomer Juni , 88.

N, S. (1992). Ilmu Pendidikan. Bandung: Remaja Rosdiana.

Nata, A. (2017). Akhlak Tasawuf dan Karakter Mulia. Jakarta: Rajawali Pers.

Nisa, Ishmatun. (2012) Analisis Semiotika Pesan Moral Dalam Film Jokowi. Jakarta: UIN Syarif Hidayatullah.

Sahide, A. (2010). Kebebasan dan Moralitas. Yogyakarta: PAS.

Sujana, N. (1995). Dasar-Dasar Proses Belajar Mengajar. Bandung: Sinar Baru Algensindo.

Surur, M. (2010). Problematika Pendidikan Moral di Sekolah dan Upaya Pemecahannya. Fikroh Volume. 4. Nomer. 2. Januari, 2.

Wahid, A. H. (2018). Smart Parenting Demokratis Dalam Membangun Karakter Anak. Al-Athfal Jurnal Pendidikan Anak Volume. 4, Nomer. 01 Juni , 2.

Ya'kub, H. (1996). Etika Islam. Bandung: Diponegoro.

Zubaedi. (2012). Desain Pendidikan Karakter: Kerangka dan Aplikasinya dalam Lembaga Pendidikan. Jakarta: Kencana Prenada Media.

Zubair, A. C. (1980). Kuliah Etika. Jakarta: Rajawali Pers.

Zuriah, N. (2007). Pendidikan Moral Dalam Budi Pekerti Dalam Perspektif Perubahan. Jakarta: Bumi Aksara. 